\title{
BMJ Open Individual and contextual predictors of emergency department visits among community-living older adults: a register-based prospective cohort study
}

\author{
Mahwish Naseer (D) , ${ }^{1,2}$ Kevin J McKee, ${ }^{1}$ Anna Ehrenberg, ${ }^{1}$ Pär Schön, ${ }^{2}$ \\ Lena Dahlberg (10) ${ }^{1,2}$
}

To cite: Naseer M, J McKee K, Ehrenberg A, et al. Individual and contextual predictors of emergency department visits among communityliving older adults: a register-based prospective cohort study. BMJ Open 2022;12:e055484. doi:10.1136/ bmjopen-2021-055484

- Prepublication history for this paper is available online. To view these files, please visit the journal online (http://dx.doi org/10.1136/bmjopen-2021 055484).

Received 13 July 2021 Accepted 21 January 2022

Check for updates

(C) Author(s) (or their employer(s)) 2022. Re-use permitted under CC BY. Published by BMJ.

${ }^{1}$ School of Health and Welfare, Dalarna University, Falun,

Sweden

${ }^{2}$ Aging Research Center, Department of Neurobiology, Care Sciences and Society, Karolinska Institutet, Stockholm, Sweden

Correspondence to

Mahwish Naseer; mna@du.se

\section{ABSTRACT}

Objectives To examine the extent to which contextual factors explain emergency department (ED) visits and ED revisits, additional to that explained by individual factors. Design A register-based prospective cohort study. Setting Swedish region of Dalarna.

Participants Participants were 16543 community-living adults aged 80 or older who were residents of the Dalarna region of Sweden, excluding older adults who moved out of Dalarna or into residential care during the study period. Outcome measures Dependent variables were initial ED visit, and at least one ED revisit within 30 days of an initial ED visit.

Results Approximately $36 \%$ of the participants visited the ED during the study period with $18.9 \%$ returning to the ED within 30 days. For both initial ED visits and ED revisits, the addition of contextual factors to models containing individual factors significantly improved model fit $(p<0.001 ; p<0.022)$ and the amount of variance explained in the outcome. In the final models, initial ED visit was significantly associated with older age, number of chronic diseases, receipt of home help, number of primary care visits, proportion of $80+$ in the population and shorter distance to the ED; while an ED revisit was significantly associated with greater use of social care, number of hospital admissions and disposition (discharged; admitted to hospital) at initial ED visit.

Conclusion Contextual factors explain variance in initial ED visit, additional to that explained by individual factors alone, which indicates inequitable access to ED care. These findings suggest considering local variations in contextual factors in order to improve health-related outcomes among older adults.

\section{INTRODUCTION}

Emergency department (ED) visits are increasing worldwide, resulting in crowding and concern about the appropriateness of such visits. ${ }^{1}$ A systematic review on $\mathrm{ED}$ visits found that older adults accounted for $12 \%-21 \%$ of all ED visits. ${ }^{2}$ In Sweden, adults aged 80 years or older constitute $5 \%$ of the total population yet account for $18 \%$ of all ED visits. ${ }^{3}$ Older adults' complex health needs are associated with a
Strengths and limitations of this study

- Contextual factors were included in this study that sought to explain emergency department visits and revisits, this has rarely been done previously.

- This was a register-based cohort study with robust information on the health and social care use of the entire older adult population.

- Home help receipt was measured using both level and quality of home help.

- Administrative differences in how municipalities report data may impact the reliability of municipallevel data.

relatively high use of health services but do not necessarily imply a requirement of ED care, ${ }^{2}$ which is often poorly adapted to such needs and may carry a risk of negative outcomes. ${ }^{45}$ While ED providers offer services/treatment for health problems and injuries that require immediate attention, some ED visits are partly explained by an unmet need for primary and social care for older adults ${ }^{26}$

The well-established Andersen model of health service use proposes the consideration of contextual factors along with individual factors for a better understanding of healthcare use. ${ }^{7}$ Briefly, contextual factors include community characteristics and service providerrelated factors that are measured at an aggregated level. Contextual factors, in the same way as individual factors, have been divided into three major components, that is, factors that predispose (eg, proportion of $80+$ in the total population), enable (eg, supply of social and healthcare facilities), or approximate individual need for healthcare (eg, disability rate). ${ }^{7}$ In this study, we explored whether considering contextual factors in addition to individual factors can improve our understanding of ED visits among older adults. 
Individual factors such as age, gender and health problems could potentially explain ED visits. There are mixed findings on the association between old age and ED visits, ${ }^{8-10}$ possibly due to inconsistent methodology. There are higher odds of ED revisits among men. ${ }^{811}$ Primary and social care play an important role in managing chronic diseases and in the proactive treatment of health problems that might require an ED visit. ${ }^{2}$ However, research has shown that home help receipt and greater use of primary care are associated with ED revisits and unplanned hospitalisations. ${ }^{11}{ }^{12}$ While it is logical that greater need for care should be associated with greater use of services, service use does not necessarily ensure that care needs are met. ${ }^{13}$ Low staff competence and poor continuity of care entails a risk of unmet needs ${ }^{14}$ and may lead to avoidable ED visits. In Sweden, the proportion of registered nurses in municipal social care for older adults is lower than in neighbouring Norway (9\% vs $31 \%),{ }^{15}$ while currently a person receiving home help meets an average of 16 different carers during a 14-day period. ${ }^{3}$ Research investigating use of healthcare services among older adults has usually included a measure of home help receipt per se, rather than measuring its level (instrumental services, personal care or both) and quality. ${ }^{11} 1216$

Contextual factors related to healthcare use include community characteristics such as the population age distribution, geographical location and the organisation of health and social care. ${ }^{7}$ In Sweden, health and social care is financed, managed and provided by 21 regions and 290 municipalities, with local variations in the management and delivery of care services. For example, without national guidelines on eligibility, municipalities decide on eligibility criteria for home help and residential care services. ${ }^{17}$ This challenges the idea that all citizens in a universal welfare state should have equitable access to high quality care services driven by their need rather than, for example, place of residence. ${ }^{18} 19$

Health and social care systems internationally have undergone substantial changes. For example, Sweden has the lowest per capita hospital bed rate in Europe,${ }^{20}$ contributing to shorter lengths of hospital stay and an increased need of primary care, while there has been a $30 \%$ reduction in residential care since $2000 .{ }^{17}$ A growing proportion of older adults are thus ageing at home and the availability of home help services is key to their living independently. ${ }^{21}$ However, home help provision has not compensated for the decrease in residential care. ${ }^{22}$ Instead, there has been an increase in informal care, particularly for older adults with lower education, while those with higher education are more likely to buy private services. ${ }^{18}$

It is important to explore contextual factors potentially influencing ED use among older adults. Or and Penneau found that shorter distance to the ED and unavailability of primary care are associated with ED visits. ${ }^{23}$ Studies on social care supply for older adults have shown that higher social care expenditures and greater availability of residential care are negatively associated with ED revisits. ${ }^{21} 24$
However, there are few studies on the association between home help coverage and ED visits. ${ }^{21}$

In summary, while both individual and contextual factors have the potential to explain ED care use in older adults, research has primarily focused on individual factors. Moreover, few studies on ED visits and revisits have considered the level and quality of home help receipt.

The aim of this study is to examine the extent to which contextual factors can improve the explanation of initial ED visits and ED revisits by community-living older adults, compared with that provided by individual factors alone.

\section{METHODS}

\section{Study design, setting and population}

A prospective cohort design was used. The study population was community-living adults aged 80 or older who were residents of the Swedish region of Dalarna on 31 December $2014(\mathrm{~N}=17$ 077). Excluding older adults who moved out of Dalarna $(\mathrm{N}=65)$ or into residential care during $2015(\mathrm{~N}=469)$, the analytical sample was $\mathrm{N}=16543$.

There are 15 municipalities in Dalarna whose population densities vary from 1.0 to 90.1 persons $/ \mathrm{km}^{2}$. Thus, great geographical variation is expected in healthcare and social care access. There are four hospital EDs in Dalarna, all open 24 hours; one is regional, three are local, of which one is only for psychiatric emergencies.

\section{Patient and public involvement}

Patients or the public were not involved in the design or conduct of study.

\section{Data sources}

This study is based on data from three registers: two national (the Longitudinal Integration Database for Health Insurance and Labour Market (LISA) and the Social Services Register) and one regional (the healthcare database of Region Dalarna), all of which cover their respective entire populations. The registers were linked via encrypted personal numbers that are assigned to all individuals living in Sweden. Municipal-level data were accessed from the publicly available national database Kolada (https://www.kolada.se/), which is managed by the Council for the Promotion of Municipal Analyses. ${ }^{25}$

\section{Dependent variables}

There were two dependent variables (DVs): (1) initial ED visit during 2015 and (2) at least one ED revisit within 30 days of an initial ED visit (both coded as no (0); yes (1)). ${ }^{911}$ Information on visits at the four EDs was obtained from the regional database.

\section{Independent variables}

Individual factors

Individual factors were categorised into two domains: (1) demographic and health characteristics, and (2) home help receipt and healthcare use. 


\section{Demographics and health}

Information on age in 2014 based on date of birth, gender and municipality of residence was obtained from LISA. Information on registered diagnosis (based on ICD-10) classification) at inpatient and outpatient visits during 2014 was obtained from the regional database and converted using a validated measure of chronic multimorbidity in older adults into number of chronic diseases. ${ }^{26}$

\section{Home help receipt and healthcare use}

Information on home help receipt status at ED visit (or status in December 2014 for those who did not visit the ED during the study period) was obtained from the Social Services Register, which is updated monthly. Home help receipt status was measured as approvals of home help services. Home help receipt was categorised as no home help, only instrumental services (eg, cleaning, shopping), only personal care (eg, hygiene) and both instrumental services and personal care.

Information on number of primary care visits, specialist care visits and hospital admissions 12 months prior to the initial ED visit (or during 2014 for those who did not visit the ED during the study period) and disposition at ED visit (discharged; admitted to hospital) was obtained from the regional database, the latter independent variable (IV) only analysed in relation to the ED revisit $\mathrm{DV}$.

\section{Contextual factors}

Contextual factors covered municipality-level data from 2015 on: the proportion of persons aged 80+ years in the total population; annual social care expenditures per person aged 80+ years; home help quality; median days in residential care for adults aged $65+$ resident in long-term care facilities; and distance to the ED. Distance to the ED which was estimated via Google maps and measured in kilometres as the shortest route from the centre of the municipality of residence to the nearest ED. ${ }^{23}$ Since the ED in Säter is only for psychiatric care it was excluded in this estimation.

Two indicators were used of home help quality, based on data from an annual national survey distributed to adults aged $65+$ years receiving home help and residential care. ${ }^{27}$ Each indicator comprises the proportion of individuals within each municipality who provided only positive responses to questions on home help quality, with three questions in each of two domains: (1) response, trust and safety (do home help staff usually respond well to you; do you trust the staff who come to your home; do you feel safe living in your home with the support of home help) and (2) influence and adequate time (do home help staff usually take account of your suggestions and wishes on how help should be provided; can you usually influence the time at which home help staff come to your place; do home help staff usually have adequate time to perform all their tasks at your place).

\section{Data analysis}

SPSS V.27 for Windows was used to conduct all analyses. Descriptive analyses were performed for all individual factors for the total sample and within municipalities, and for contextual factors at the municipality level. ORs with 95\% CIs were calculated for the bivariate associations between individual and contextual factors (independent variables, IVs) and ED visits and ED revisits (DVs).

Subsequently, all IVs with a significant bivariate association with the DVs were used to develop multivariable models of the DVs. First, since the data for ED visits and ED revisits were nested within municipalities, the relevance of nested models was tested by generalised linear mixed models. ${ }^{28}$ The variance estimate at municipality level was 0.064 for initial ED visit and 0.019 for revisit, providing an intraclass coefficient of 0.019 and 0.005 . Thus, only $1.9 \%$ of the variance in initial visit and $0.57 \%$ in revisit was explained by municipality of residence, that is, considerably below the conventional level indicating a multilevel analysis is required. ${ }^{29}$ Therefore, we proceeded with sequential logistic regression.

Model building proceeded in three steps. At the first step, individual demographic and health characteristics were entered in the models. At the second step, individual home help receipt and healthcare use were entered in the models and changes in model fit statistics examined. At the third step, contextual factors were entered in the models to determine if there was significant improvement in the models after entry of all individual factors. The deviance statistic (-2LL), Cox and Snell's $\mathrm{R}^{2}$ and Nagelkerke $\mathrm{R}^{2}{ }_{\mathrm{N}}$ test were used for model fitting. ${ }^{30}$ The deviance describes the unexplained variance in the model, so the smaller the value of deviance, the better the model fits the data. $\mathrm{R}^{2}{ }_{\mathrm{CS}}$ and $\mathrm{R}_{\mathrm{N}}^{2}$ are approximations to the $\mathrm{R}^{2}$ statistic for multiple linear regression which describes the variance in the DV explained by the model. $\mathrm{R}^{2}{ }_{\mathrm{CS}}$ and $\mathrm{R}_{\mathrm{N}}^{2}$ are calculated differently and may provide divergent estimates, thus both were included. ${ }^{30}$

Variance inflation factor (VIF) was used to check potential multicollinearity among IVs. VIF values were below 10 for all the IVs and considered acceptable. ${ }^{31}$

\section{RESULTS}

\section{Descriptive analyses}

The mean age of the participants was 85.2 years and $58.5 \%$ were women (table 1 ). The mean number of chronic diseases was 2.1 (range 1.8-2.4 across municipalities). Seventy-four per cent lived at home with no home help, while $5.1 \%$ received instrumental services only, $3.9 \%$ personal care only and $16.3 \%$ received instrumental services and personal care (range for home help receipt $19.1 \%-37.1 \%)$.

The mean number of primary care visits was 9.0 (range 7.5-10.4), while the mean number of specialist care visits was 2.7 (range 1.7-4.1) (table 2). The mean number of hospital admissions was 0.3 (range 0.3-0.4). In the sample, $36.4 \%$ had at least one ED visit, of whom $18.9 \%$ 
Table 1 Demographic, health and home help use characteristics for total study participants ( $N=16543$ ) and stratified by municipality

\begin{tabular}{|c|c|c|c|c|c|c|c|c|}
\hline \multirow[b]{3}{*}{ Municipality } & \multirow[b]{3}{*}{$\mathbf{n}$} & \multicolumn{2}{|c|}{ Demographics } & \multirow{2}{*}{$\begin{array}{l}\text { Health } \\
\begin{array}{l}\text { No of chronic } \\
\text { diseases }\end{array}\end{array}$} & \multicolumn{2}{|c|}{ Home help } & \multirow[b]{2}{*}{$\begin{array}{l}\text { Personal } \\
\text { care }\end{array}$} & \multirow[b]{2}{*}{$\begin{array}{l}\text { Instrumental and } \\
\text { personal care }\end{array}$} \\
\hline & & Age & $\begin{array}{l}\text { Female } \\
\text { gender }\end{array}$ & & No & $\begin{array}{l}\text { Instrumental } \\
\text { services }\end{array}$ & & \\
\hline & & $\begin{array}{l}\text { Mean } \\
\text { (SD) }\end{array}$ & $\%$ & $\begin{array}{l}\text { Mean } \\
\text { (SD) }\end{array}$ & $\%$ & $\%$ & $\%$ & $\%$ \\
\hline \multirow{2}{*}{ Avesta } & 1474 & 85.1 & 57.1 & 2.4 & 80.5 & 3.1 & 2.1 & 14.2 \\
\hline & & $(4.1)$ & & (2.0) & & & & \\
\hline \multirow[t]{2}{*}{ Borlänge } & 2599 & 85.1 & 57.5 & 2.0 & 72.0 & 1.3 & 12.5 & 14.2 \\
\hline & & $(4.2)$ & & (1.8) & & & & \\
\hline \multirow[t]{2}{*}{ Falun } & 2925 & 85.2 & 58.5 & 2.2 & 62.9 & 14.0 & 1.1 & 22.0 \\
\hline & & $(4.2)$ & & (1.8) & & & & \\
\hline \multirow[t]{2}{*}{ Gagnef } & 539 & 85.1 & 54.2 & 2.1 & 79.8 & 2.0 & 4.0 & 14.1 \\
\hline & & $(4.0)$ & & $(1.7)$ & & & & \\
\hline \multirow[t]{2}{*}{ Hedemora } & 932 & 85.1 & 59.5 & 2.2 & 78.8 & 2.3 & 2.0 & 16.8 \\
\hline & & $(4.2)$ & & (1.9) & & & & \\
\hline \multirow[t]{2}{*}{ Leksand } & 945 & 85.4 & 59.0 & 1.8 & 78.7 & 2.7 & 2.7 & 15.9 \\
\hline & & $(4.2)$ & & $(1.7)$ & & & & \\
\hline \multirow[t]{2}{*}{ Ludvika } & 1732 & 85.5 & 60.9 & 2.1 & 75.6 & 6.6 & 2.1 & 15.6 \\
\hline & & $(4.3)$ & & $(1.8)$ & & & & \\
\hline \multirow[t]{2}{*}{ Malung-Sälen } & 633 & 84.8 & 59.1 & 2.2 & 77.3 & 3.4 & 2.3 & 16.9 \\
\hline & & $(4.1)$ & & (1.9) & & & & \\
\hline \multirow[t]{2}{*}{ Mora } & 1215 & 85.4 & 59.6 & 2.0 & 78.2 & 2.2 & 2.8 & 16.7 \\
\hline & & $(4.4)$ & & (1.9) & & & & \\
\hline \multirow[t]{2}{*}{ Orsa } & 477 & 85.1 & 58.5 & 2.3 & 78.8 & 2.5 & 3.1 & 15.5 \\
\hline & & $(4.1)$ & & (2.0) & & & & \\
\hline \multirow[t]{2}{*}{ Rättvik } & 905 & 85.3 & 60.0 & 1.9 & 80.8 & 4.2 & 1.5 & 13.5 \\
\hline & & $(4.1)$ & & $(1.8)$ & & & & \\
\hline \multirow[t]{2}{*}{ Smedjebacken } & 617 & 84.8 & 55.9 & 2.1 & 78.1 & 6.0 & 4.5 & 11.3 \\
\hline & & $(4.0)$ & & (1.8) & & & & \\
\hline \multirow[t]{2}{*}{ Säter } & 591 & 85.2 & 57.9 & 2.1 & 76.3 & 4.0 & 3.0 & 16.6 \\
\hline & & $(4.2)$ & & $(1.8)$ & & & & \\
\hline \multirow[t]{2}{*}{ Vansbro } & 440 & 84.9 & 58.6 & 2.1 & 80.9 & 0.9 & 4.7 & 13.4 \\
\hline & & $(4.0)$ & & (1.9) & & & & \\
\hline \multirow[t]{2}{*}{ Älvdalen } & 519 & 85.0 & 59.0 & 2.2 & 75.7 & 4.2 & 3.6 & 16.4 \\
\hline & & $(4.0)$ & & (1.9) & & & & \\
\hline \multirow[t]{2}{*}{ Total } & 16543 & 85.2 & 58.5 & 2.1 & 74.6 & 5.1 & 3.9 & 16.3 \\
\hline & & $(4.2)$ & & $(1.8)$ & & & & \\
\hline
\end{tabular}

had an ED revisit within 30 days. The mean number of ED visits was 0.7 (range $0.4-0.9$ ).

Contextual factors are presented in table 3. The proportion of adults aged $80+$ years varied across municipalities from $5.3 \%$ to $9.0 \%$, while social care costs per person varied from Swedish Korona (SEK) 207741 to SEK272,317 during 2015 (approx. US $\$ 25000-U S \$ 32$ 000). Positive home help quality varied between $35.0 \%$ and $56.0 \%$ for response, trust and safety and between $34.0 \%$ and $60.0 \%$ for influence and adequate time.
Median days in residential care varied between 407 and 867 , while distance to the nearest ED varied from $1.8 \mathrm{~km}$ to $78.8 \mathrm{~km}$.

\section{Initial ED visit}

In bivariate analyses, individual factors significantly positively associated with initial ED visit were: age, number of chronic diseases, home help receipt, number of primary care visits, specialist care visits and hospital admissions (table 4). Contextual factors significantly negatively 
Table 2 Healthcare use for participants ( $N=16543$ ) and stratified by municipality

\begin{tabular}{|c|c|c|c|c|c|c|c|}
\hline & & $\begin{array}{l}\text { No of primary } \\
\text { care visits }\end{array}$ & $\begin{array}{l}\text { No of specialist } \\
\text { care visits }\end{array}$ & $\begin{array}{l}\text { No of hospital } \\
\text { admissions }\end{array}$ & $\begin{array}{l}\text { ED visits } \\
\text { (Yes) }\end{array}$ & $\begin{array}{l}\text { No of ED } \\
\text { visits }\end{array}$ & $\begin{array}{l}\text { ED } \\
\text { revisit* }\end{array}$ \\
\hline Municipality & $\mathbf{N}$ & $\begin{array}{l}\text { Mean } \\
\text { (SD) }\end{array}$ & $\begin{array}{l}\text { Mean } \\
\text { (SD) }\end{array}$ & $\begin{array}{l}\text { Mean } \\
\text { (SD) }\end{array}$ & $\%$ & $\begin{array}{l}\text { Mean } \\
\text { (SD) }\end{array}$ & $\%$ \\
\hline \multirow[t]{2}{*}{ Avesta } & 1474 & 7.5 & 3.0 & 0.4 & 38.9 & 0.8 & 23.5 \\
\hline & & (8.0) & (8.1) & $(0.9)$ & & (1.5) & \\
\hline \multirow[t]{2}{*}{ Borlänge } & 2599 & 8.6 & 2.6 & 0.3 & 36.0 & 0.6 & 20.0 \\
\hline & & (9.3) & (8.5) & $(0.8)$ & & (1.1) & \\
\hline \multirow[t]{2}{*}{ Falun } & 2925 & 10.4 & 2.9 & 0.3 & 41.8 & 0.8 & 19.1 \\
\hline & & (10.8) & (9.3) & $(0.8)$ & & (1.6) & \\
\hline \multirow[t]{2}{*}{ Gagnef } & 539 & 8.4 & 2.2 & 0.3 & 34.0 & 0.6 & 21.3 \\
\hline & & (10.3) & (6.6) & $(0.8)$ & & (1.2) & \\
\hline \multirow[t]{2}{*}{ Hedemora } & 932 & 8.1 & 2.5 & 0.3 & 36.8 & 0.7 & 22.3 \\
\hline & & (8.5) & (7.1) & $(0.8)$ & & (1.4) & \\
\hline \multirow[t]{2}{*}{ Leksand } & 945 & 10.2 & 1.9 & 0.3 & 36.2 & 0.7 & 16.2 \\
\hline & & (10.9) & (3.7) & $(0.8)$ & & (1.3) & \\
\hline \multirow[t]{2}{*}{ Ludvika } & 1732 & 8.8 & 3.0 & 0.3 & 26.2 & 0.4 & 15.6 \\
\hline & & $(9.8)$ & (9.0) & $(0.8)$ & & $(0.9)$ & \\
\hline \multirow[t]{2}{*}{ Malung-Sälen } & 633 & 9.2 & 2.0 & 0.3 & 28.1 & 0.4 & 13.0 \\
\hline & & $(9.0)$ & (7.4) & $(0.7)$ & & $(0.9)$ & \\
\hline \multirow[t]{2}{*}{ Mora } & 1215 & 9.2 & 3.3 & 0.4 & 44.7 & 0.9 & 17.8 \\
\hline & & (8.6) & $(9.4)$ & $(0.9)$ & & (1.6) & \\
\hline \multirow[t]{2}{*}{ Orsa } & 477 & 8.4 & 4.1 & 0.4 & 44.9 & 0.8 & 17.8 \\
\hline & & $(8.7)$ & (16.8) & $(0.8)$ & & (1.4) & \\
\hline \multirow[t]{2}{*}{ Rättvik } & 905 & 8.4 & 2.3 & 0.3 & 37.2 & 0.7 & 21.1 \\
\hline & & $(9.0)$ & (6.4) & $(0.8)$ & & (1.2) & \\
\hline \multirow[t]{2}{*}{ Smedjebacken } & 617 & 8.9 & 2.2 & 0.3 & 26.1 & 0.4 & 15.0 \\
\hline & & (8.3) & (5.5) & $(0.8)$ & & $(0.9)$ & \\
\hline \multirow[t]{2}{*}{ Säter } & 591 & 9.2 & 1.7 & 0.3 & 33.3 & 0.5 & 13.9 \\
\hline & & (9.8) & (3.8) & $(0.7)$ & & (1.1) & \\
\hline \multirow[t]{2}{*}{ Vansbro } & 440 & 9.8 & 2.2 & 0.3 & 31.4 & 0.5 & 18.4 \\
\hline & & (9.6) & (7.0) & (0.8) & & (1.1) & \\
\hline \multirow[t]{2}{*}{ Älvdalen } & 519 & 8.5 & 2.6 & 0.3 & 38.2 & 0.6 & 17.6 \\
\hline & & (9.2) & (12.2) & $(0.7)$ & & (1.1) & \\
\hline \multirow[t]{2}{*}{ Total } & 16543 & 9.0 & 2.7 & 0.3 & 36.4 & 0.7 & 18.9 \\
\hline & & (9.6) & (8.5) & $(0.8)$ & & (1.3) & \\
\hline
\end{tabular}

*Sample for ED revisit includes only those who visited ED ( $n=5930)$. ED, emergency department.;

associated with ED visits were: median days in residential care, proportion of adults $80+$ years in the population and greater distance to the ED.

In model 1 with the demographic and health characteristics age and number of chronic conditions included, deviance $=20624.7, \mathrm{R}^{2}{ }_{\mathrm{CS}}=0.062$ and $\mathrm{R}_{\mathrm{N}}^{2}=0.085$. Compared with a constant-only model, model 1 is a significant improvement $\left(\chi^{2}(2)=1065.2, p<0.001\right)$. In model 2 with the addition of variables measuring home help and healthcare use, deviance $=19883.9, \mathrm{R}_{\mathrm{CS}}^{2}=0.103$ and $\mathrm{R}_{\mathrm{N}}^{2}=0.142$. Compared with model 1 , model 2 is a significant improvement (model $\left.\chi^{2}(8)=1806.1, \mathrm{p}<0.001 ; \operatorname{step} \chi^{2}(6)=740.9, \mathrm{p}<0.001\right)$. In model 3 with the addition of variables measuring contextual factors, deviance $=19701.7, \mathrm{R}_{\mathrm{CS}}^{2}=0.113$ and $\mathrm{R}_{\mathrm{N}}^{2}=0.155$. Compared with model 2, model 3 is a significant improvement (model $\chi^{2}(11)=1988.3, p<0.001$; step $\chi^{2}(3)=182.2, p<0.001$. Thus, the multivariable models indicated a better fit at each step.

In the final multivariable model (model 3), individuallevel factors with significant higher ORs for ED visits were: age, number of chronic diseases, home help receipt, and number of primary care visits. Contextual factors 
Table 3 Contextual factors at municipality level

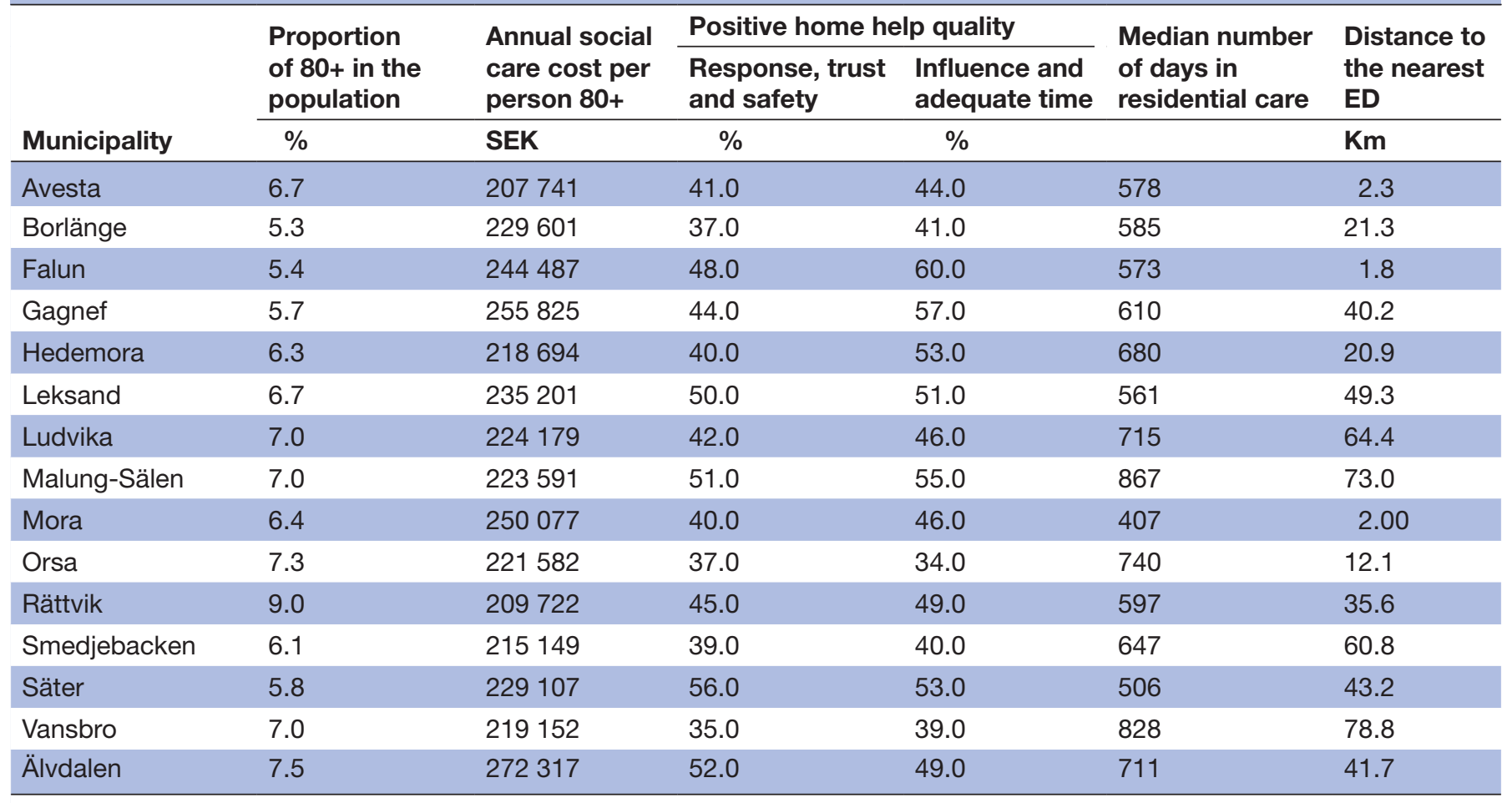

ED, emergency department; SEK, Swedish Korona.

significantly associated with ED visit were: higher proportion of adults $80+$ years in the total population and shorter distance to the ED.

\section{ED revisit}

In bivariate analyses, number of chronic diseases, receipt of both instrumental and personal care from home help services, number of primary care visits and hospital admissions prior to initial ED visit were significantly positively associated with ED revisit, while being admitted to hospital at initial ED visit was significantly negatively associated with an ED revisit (table 5). Of the contextual factors, distance to the ED was significantly negatively associated with an ED revisit.

In model 1 with the health characteristic number of chronic conditions included, deviance $=5718.9$, $\mathrm{R}^{2}{ }_{\mathrm{CS}}=0.004$ and $\mathrm{R}_{\mathrm{N}}^{2}=0.006$. Compared with a constantonly model, model 1 is a significant improvement $\left(\chi^{2}(1)=22.4, p<0.001\right)$. In model 2 with the addition of variables measuring home help and healthcare use, deviance $=5650.0, \mathrm{R}_{\mathrm{CS}}^{2}=0.015$ and $\mathrm{R}_{\mathrm{N}}^{2}=0.025$. Compared with model 1 , model 2 is a significant improvement (model $\chi^{2}(7)=91.3, \mathrm{p}<0.001$; step $\left.\chi^{2}(6)=68.9, \mathrm{p}<0.001\right)$. In model 3 with the addition of the contextual factor distance to the nearest $\mathrm{ED}$, deviance $=5644.8, \mathrm{R}_{\mathrm{CS}}^{2}=0.016$ and $\mathrm{R}_{\mathrm{N}}^{2}=0.026$. Compared with model 2, model 3 is a significant improvement $\left(\operatorname{model} \chi^{2}(8)=96, \mathrm{p}<0.001\right.$; step $\left.\chi^{2}(1)=5.26, \mathrm{p}<0.022\right)$. Thus, the multivariable models indicated a better fit at each step.

In the final multivariable model (model 3), receipt of both instrumental and personal care from home help services, number of hospital admissions, and disposition at initial ED visit were significantly associated with ED revisits. Although the addition of distance to nearest ED in model 3 resulted in a significant improvement in model fit compared with model 2, as the CIs of the OR for the variable contains 1 we conclude that the association between distance to ED and ED revisit was not significant in the model.

\section{DISCUSSION}

\section{Main findings}

Approximately $36 \%$ of the participants visited the ED, of whom $18.9 \%$ had an ED revisit within 30 days. Research has mainly focused on individual predictors of ED care. Our study indicates that ED care can be further explained by contextual factors. Contextual factors associated with higher odds of initial ED visit indicate inequitable access to ED care. Receipt of both instrumental services and personal care is an important predictor of ED visits and revisits.

\section{Comparison with other studies}

Our findings on the associations between age, number of chronic diseases and initial ED visits are in line with Andersen's model, which describes equitable access to ED care explained by demographic factors (eg, age) and need (eg, chronic diseases). ${ }^{7}$ Health decline with age and multimorbidity relates to the increasing need for healthcare. Grunier et al argued that social and primary care can play a role in the management of need and can contribute 
Table 4 Models for binary logistic regression of factors associated with initial ED visit ( $N=16543)$

\begin{tabular}{|c|c|c|c|c|}
\hline & \multicolumn{4}{|l|}{ ED visit } \\
\hline & Bivariate & Model 1 & Model 2 & Model 3 \\
\hline & OR $(95 \% \mathrm{Cl})$ & OR $(95 \% \mathrm{Cl})$ & OR $(95 \% \mathrm{Cl})$ & OR $(95 \% \mathrm{Cl})$ \\
\hline \multicolumn{5}{|l|}{ Individual factors } \\
\hline \multicolumn{5}{|l|}{ Demographics and health } \\
\hline Age & $1.08(1.07 \text { to } 1.09)^{*}$ & $1.09(1.08 \text { to } 1.09)^{\star}$ & $1.06(1.05 \text { to } 1.06)^{*}$ & $1.06(1.05 \text { to } 1.07)^{x}$ \\
\hline \multicolumn{5}{|l|}{ Gender } \\
\hline Male & $1.04(0.97$ to 1.11$)$ & & & \\
\hline No of chronic diseases & $1.22(1.20 \text { to } 1.25)^{*}$ & $1.24(1.21 \text { to } 1.26)^{*}$ & $1.12(1.10 \text { to } 1.15)^{*}$ & $1.12(1.10 \text { to } 1.15)^{x}$ \\
\hline \multicolumn{5}{|l|}{ Home help and healthcare use } \\
\hline \multicolumn{5}{|l|}{ Home help } \\
\hline No & Ref & & Ref & Ref \\
\hline No of primary care visits & $1.05(1.04 \text { to } 1.05)^{\star}$ & & $1.03(1.03 \text { to } 1.04)^{*}$ & $1.03(1.03 \text { to } 1.04)^{\star}$ \\
\hline No of specialist care visits & $1.02(1.01 \text { to } 1.02)^{*}$ & & $1.00(1.00$ to 1.01$)$ & $1.00(1.00$ to 1.01$)$ \\
\hline No of hospital admissions & $1.37(1.32 \text { to } 1.42)^{\star}$ & & 1.01 (0.96 to 1.05$)$ & 1.00 (0.96 to 1.05$)$ \\
\hline \multicolumn{5}{|l|}{ Contextual factors } \\
\hline Annual social care cost per person $80+$ & 1.00 (1.00 to 1.00$)$ & & & \\
\hline Response, trust and safety & 1.00 (0.99 to 1.00$)$ & & & \\
\hline Influence and adequate time & $1.00(1.00$ to 1.01$)$ & & & \\
\hline Median days in residential care & $0.99(0.99 \text { to } 0.99)^{\star}$ & & & $1.00(0.99$ to 1.00$)$ \\
\hline Proportion of $80+$ in the population & $0.94(0.91 \text { to } 0.98)^{\star}$ & & & $1.09(1.05 \text { to } 1.13)^{*}$ \\
\hline
\end{tabular}

Note: The negative bivariate association for proportion of $80+$ in the population with initial ED visit becomes a positive association and increases in magnitude in the multivariable model, indicating negative suppression. Through trial variable removal from the model, ${ }^{30}$ it was determined that distance to the ED and median days in residential care both acted as suppressor variables for proportion $80+$ in the population.

*Significant on values estimated from $95 \% \mathrm{Cl}$.

$\mathrm{ED}$, emergency department.

positively to reducing ED visits. Our study shows that the addition of home help and healthcare variables increased the variance explained in DVs by demographics and health characteristics and improved the overall model fit. Positive associations between initial ED visit and both home help receipt and primary care visits suggest that the provided services do not meet the recipient's care needs, ${ }^{2}$ that is, indicate a poorly functioning health and social care system. However, extensive home help provision is also an indication of poor health/functional status with an increased risk for ED visits.

The needs of older adults are often complex, and inadequate care co-ordination between hospitals, primary and municipal social care for older adults increases the risk of negative health outcomes. In Sweden, as in other high-income countries, the fragmentation of health and social care systems has become more visible during the COVID-19 pandemic, and there is a need to establish channels that ensure continuous and rapid coordination of services from different care providers and levels of organisations. ${ }^{32} 33$ Research has shown that integrated care, that is, co-ordination between different care providers, can reduce ED visits, hospital admissions, and the length of hospital stay. ${ }^{34} 35$

The ED visit models explain more variance in the outcome than the revisit model and more IVs are significant in the model, including contextual factors. This may be partly explained by the revisit models having less variation in its $\mathrm{DV}$, and perhaps also due to $\mathrm{ED}$ revisits more than initial ED visit being related to extraneous variables that were not available in the registers accessed and thus not included in the models. The odds of revisits were higher in those who were not admitted to inpatient hospital care at initial visit and among those with greater use of home help services and higher number of hospital admissions. With shorter lengths of hospital 
Table 5 Models for logistic regression of factors associated with ED revisit within 30 days after initial ED visit ( $N=5930)$

\section{ED revisit}

\begin{tabular}{llll}
\hline Bivariate & Model 1 & Model 2 & Model 3 \\
\hline OR $(95 \% \mathrm{Cl})$ & OR $(95 \% \mathrm{Cl})$ & OR $(95 \% \mathrm{Cl})$ & OR $(95 \% \mathrm{Cl})$
\end{tabular}

\section{Individual factors}

\section{Demographics and health}

\begin{tabular}{|c|c|c|c|c|}
\hline Age & 0.99 (0.98 to 1.01$)$ & & & \\
\hline \multicolumn{5}{|l|}{ Gender } \\
\hline Female & Ref. & & & \\
\hline No of chronic diseases & $1.07(1.04 \text { to } 1.10)^{*}$ & $1.07(1.04 \text { to } 1.10)^{*}$ & $1.02(0.98$ to 1.06$)$ & $1.02(0.98$ to 1.06$)$ \\
\hline \multicolumn{5}{|l|}{ Home help and healthcare use } \\
\hline Instrumental services & 0.99 (0.75 to 1.32$)$ & & 0.99 (0.74 to 1.32$)$ & 0.97 (0.73 to 1.29$)$ \\
\hline Personal care & $1.13(0.84$ to 1.53$)$ & & $1.13(0.84$ to 1.53$)$ & 1.15 (0.85 to 1.55$)$ \\
\hline Instrumental and personal care & $1.33(1.15 \text { to } 1.55)^{*}$ & & $1.31(1.13 \text { to } 1.53)^{\star}$ & $1.30(1.12 \text { to } 1.51)^{\star}$ \\
\hline No of primary care visits & $1.01(1.01 \text { to } 1.02)^{\star}$ & & $1.00(1.00$ to 1.01$)$ & $1.00(1.00$ to 1.01$)$ \\
\hline Discharged & Ref & & Ref & Ref \\
\hline Hospital admission & $0.73(0.65 \text { to } 0.83)^{*}$ & & $0.69(0.61 \text { to } 0.79)^{*}$ & $0.71(0.62 \text { to } 0.81)^{*}$ \\
\hline \multicolumn{5}{|l|}{ Contextual factors } \\
\hline Annual social care cost per person $80+$ & 1.00 (1.00 to 1.00$)$ & & & \\
\hline Response, trust and safety & 0.98 (0.97 to 1.00$)$ & & & \\
\hline Influence and adequate time & 0.99 (0.99 to 1.00$)$ & & & \\
\hline Median days in residential care & 1.00 (0.99 to 1.00$)$ & & & \\
\hline Propotion of $80+$ in the population & 0.99 (0.92 to 1.06$)$ & & & \\
\hline Distance to the nearest ED & $0.99(0.99 \text { to } 0.99)^{\star}$ & & & 0.99 (0.99 to 1.00$)$ \\
\hline
\end{tabular}

*Significant on values estimated from $95 \% \mathrm{Cl}$. ED, emergency department.

stay, ${ }^{20}$ home help providers have to care for older adults with more complex care needs. ${ }^{3}$ A recent report showed that patients who were sent home after initial ED visit had a declining health status at ED revisit within 30 days, that is, that their needs for aftercare were not met. ${ }^{36}$

Our results show that contextual factors (living in municipalities with higher proportions of adults aged $80+$ in the population and a shorter distance to the ED) increased the odds of an initial ED visit at the individual level. Critical events that require ED care are common in the $80+$ group due to multiple health problems, complex needs and rapid changes in health status, which put pressure on the local healthcare system and this may explain the association between a higher proportion of $80+$ in the population and ED visits. The association between distance to the $\mathrm{ED}$ and $\mathrm{ED}$ visits raises concern on the appropriateness of such visits. Access to ED care should be driven by need rather than place of residence, and the variance in initial $\mathrm{ED}$ visit explained by contextual factors challenges the idea of universalism and equitable access to healthcare. This suggests that considering the healthcare needs of the local population and geographical variation in healthcare planning may improve the accessibility of primary and social care for older adults. ${ }^{23}$

\section{Implications}

Those individuals who receive both instrumental services and personal care constitute a vulnerable group that should be considered in interventions for reducing ED visits, discharge planning, and aftercare. Considering local variations in healthcare needs and access to health 
and social care is important for improving health-related outcomes among older adults.

\section{Strengths and limitations}

A strength of this study was that it was based on register data. Registers provide high-quality information on health and social care use covering the entire population. This study also included contextual factors in seeking to explain ED visits, which have been rarely considered previously, as well as levels and quality of home help receipt as factors in ED visits rather than simply use/non-use.

Home help receipt was categorised as an individual factor, while home help quality was categorised as a contextual variable as the individual-level data were only available for analysis as aggregated data. Thus, some variables that might explain ED visits or revisits can be optionally conceptualised and operationalised at individual or contextual levels. An association between variables can differ in strength and direction when analysed at individual vs group level, so it is important that the use of aggregated data as a contextual factor can be defended. The reliability of the data on home help quality will have been influenced by a survey response rate that varied between $48 \%$ and $66 \%$ by municipality and only $46 \%$ of the data provided by care recipients with the rest provided by relatives or care providers.

The measure of the number of chronic diseases used in this study included healthcare use in 2014 only. Patients who were admitted to the hospital compared with those discharged after the initial ED visit did not have an equal chance to be included within the 30 days criterion for an ED revisit. This problem is minor, though, since the median length of stay in hospital was 4 days. Administrative differences in how municipalities report data to the Kolada database may impact data reliability. Distance to the nearest ED was estimated from the city centre rather than place of residence. Finally, the amount of variance our models explained in their respective outcomes was not substantial, this was particularly the case for ED revisits. This is perhaps not surprising given the many factors that might potentially influence ED use and ED revisits, and indicates that future research should seek to incorporate a broader range of variables than were available for this study to advance the understanding of ED visits and revisits.

\section{CONCLUSION}

The aim of this study was to consider whether contextual factors improve our understanding of ED visits. Results suggest that contextual factors explain additional significant variance in initial ED visit compared with that explained by individual factors alone, which indicates inequitable access to ED care.

In individual factors, age and health characteristics explain variance in initial visit while receipt of home help and healthcare use explained variance both in initial visit and revisit. ED revisit was also explained by discharge from ED and can be interpreted as a result of inadequate care and discharge planning at the initial visit. Greater use of home help and primary care does not ensure that needs are met, and further research on the impact of unmet care needs in older adults on ED visits can clarify how the use of different health and social care services are associated. Local variations in home help receipt and utilisation of ED care challenge the notion of a universal welfare state, and require consideration in order to improve health-related outcomes among older adults.

Contributors Planning and study design (MN, KM, AE, PS and LD), conducted data analysis (MN), advice regarding data analysis (KM) interpreting analyses and results (MN, KM, AE, PS and LD), drafting of manuscript (MN), revising and finalising the manuscript (MN, KM, AE, PS and LD), final approval of the manuscript (MN, KM, AE, PS and LD). MN is acting as guarantor of this study.

Funding The study was supported by Swedish Research Council for Health, Working Life and Welfare (grant no. 2015-00440) and Region Dalarna.

Disclaimer The funding organisation had no role in the development of study design, analysis, and/or in manuscript writing.

Competing interests None declared.

Patient and public involvement Patients and/or the public were not involved in the design, or conduct, or reporting, or dissemination plans of this research.

Patient consent for publication Not applicable.

Ethics approval Ethical approval for the study was awarded by the Regional Ethical Review Board in Stockholm (reg.no. 2016/299-31).

Provenance and peer review Not commissioned; externally peer reviewed.

Data availability statement Data are available in a public, open access repository. Data may be obtained from a third party and are not publicly available. Individuallevel data are obtained from registers (anonymised) and are not publicly available. Municipal level data are available publicly at kolada.se.(dataset) 25 . Council for the Promotion of Municipal Analyses. Data from: Kolada; Den öppna och kostnadsfria databasen för kommuner och regioner (The free database for municipalities and regions) 2015. Kolada, 1 December 2021. https://www.kolada.se/

Open access This is an open access article distributed in accordance with the Creative Commons Attribution 4.0 Unported (CC BY 4.0) license, which permits others to copy, redistribute, remix, transform and build upon this work for any purpose, provided the original work is properly cited, a link to the licence is given, and indication of whether changes were made. See: https://creativecommons.org/ licenses/by/4.0/.

\section{ORCID iDs}

Mahwish Naseer http://orcid.org/0000-0001-7231-826X

Lena Dahlberg http://orcid.org/0000-0002-7685-3216

\section{REFERENCES}

1 Boyle A, Beniuk K, Higginson I, et al. Emergency department crowding: time for interventions and policy evaluations. Emerg Med Int 2012;2012:838610.

2 Gruneir A, Silver MJ, Rochon PA. Emergency department use by older adults: a literature review on trends, appropriateness, and consequences of unmet health care needs. Med Care Res Rev 2011;68:131-55.

3 National Board of Health and Welfare. Vård och omsorg om äldre lägesrapport 2020. In: The National report on social care for older adults. Stockholm: National Board of Health and Welfare, 2020.

4 Covinsky KE, Pierluissi E, Johnston CB. Hospitalization-associated disability: "She was probably able to ambulate, but I'm not sure". JAMA 2011;306:1782-93.

5 SBU. Omhändertagande av äldre som inkommer akut till sjukhusmed fokus på sköra äldre. En systematisk litteratur översikt [Care of older people coming to hospital emergency: a focus on frail older people. A systematic literature review. Stockholm: Swedish Agency for Health Technology Assessment, 2013.

6 Hass Z, DePalma G, Craig BA, et al. Unmet need for help with activities of daily living disabilities and emergency department 
admissions among older Medicare recipients. Gerontologist 2017;57:206-10.

7 Andersen RM. National health surveys and the behavioral model of health services use. Med Care 2008;46:647-53.

8 de Gelder J, Lucke JA, de Groot B, et al. Predictors and outcomes of revisits in older adults discharged from the emergency department. $J$ Am Geriatr Soc 2018;66:735-41.

9 Lowthian J, Straney LD, Brand CA, et al. Unplanned early return to the emergency department by older patients: the safe elderly emergency department discharge (seed) project. Age Ageing 2016;45:255-61.

10 Lynch B, Fitzgerald AP, Corcoran P, et al. Drivers of potentially avoidable emergency admissions in Ireland: an ecological analysis. BMJ Qual Saf 2019;28:438-48.

11 Naseer M, Agerholm J, Fastbom J, et al. Factors associated with emergency department revisits among older adults in two Swedish regions: a prospective cohort study. Arch Gerontol Geriatr 2020;86:103960.

12 Dahlberg L, Agahi N, Schön P, et al. Planned and unplanned hospital admissions and their relationship with social factors: findings from a national, prospective study of people aged 76 years or older. Health Serv Res 2018;53:4248-67.

13 Cunningham A, Mautner D, Ku B, et al. Frequent emergency department visitors are frequent primary care visitors and report unmet primary care needs. J Eval Clin Pract 2017;23:567-73.

14 Ernsth Bravell M, Bennich M, Walfridsson C. "In August, I Counted 24 Different Names": Swedish Older Adults' Experiences of Home Care. J App/ Gerontol 2021;40:1020-8.

15 SOU. Internationella erfarenheter av Covid-19 i äldreboende [International experiences of COVID-19 in residential care] 2020. In: Reports SOU Stockholm. 80, 2020.

16 Tanderup A, Ryg J, Rosholm J-U, et al. Association between the level of municipality healthcare services and outcome among acutely older patients in the emergency department: a Danish population-based cohort study. BMJ Open 2019;9:e026881.

17 Schön P, Heap J. European social policy network (Espn) thematic report on challenges in long-term care Sweden, 2018. Available: https://ec.europa.eu/social/main.jsp?pager.offset=30\&catld=792\& langld=en\&moreDocuments=yes [Accessed 12 Oct 2020].

18 Szebehely M, Trydegård G-B. Home care for older people in Sweden: a universal model in transition. Health Soc Care Community 2012;20:300-9.

19 Trydegård G-B, Thorslund M. One uniform welfare state or a multitude of welfare municipalities? the evolution of local variation in Swedish elder care. Soc Policy Adm 2010;44:495-511.

20 OECD. Health at a glance: Europe state of health in the EU cycle. OECD Publishing, 2020.

21 Spiers G, Matthews FE, Moffatt S, et al. Impact of social care supply on healthcare utilisation by older adults: a systematic review and meta-analysis. Age Ageing 2019;48:57-66.

22 Ulmanen P, Szebehely M. From the state to the family or to the market? consequences of reduced residential eldercare in Sweden. Int J Soc Welf 2015;24:81-92.
23 Or Z, Penneau A. A multilevel analysis of the determinants of emergency care visits by the elderly in France. Health Policy 2018;122:908-14.

24 Fernandez J-L, Forder J. Consequences of local variations in social care on the performance of the acute health care sector. Appl Econ 2008;40:1503-18.

25 Council for the Promotion of Municipal Analyses. Data from: Kolada; Den öppna och kostnadsfria databasen för kommuner och regioner [The free database for municipalities and regions] 2015, 2021. Available: https://www.kolada.se/

26 Calderón-Larrañaga A, Vetrano DL, Onder G, et al. Assessing and measuring chronic multimorbidity in the older population: a proposal for its operationalization. J Gerontol A Biol Sci Med Sci 2017;72:1417-23.

27 National Board of Health and Welfare. Så tycker de äldre om äldreomsorgen 2015: En rikstäckande undersökning i hemtjänst och äldreboenden [What older people thinks on eldercare 2015: A national survey on home help and institutional care. Stockholm: National Board of Health and Welfare, 2015.

28 Sommet N, Morselli D. Keep calm and learn multilevel logistic modeling: a simplified three-step procedure using Stata, R, mPLUS, and SPSS. International Review Social Psychology 2017;30:203-18.

29 Kreft IGG, de Leeuw J. Introducing multilevel modeling. SAGE Publications, 1998.

30 Field A. Discovering statistics using IBM SPSS statistics. 4 edn. London: SAGE Publications, 2013.

31 Myers R. Classical and modern regression with applications. 1990. In: Field A. discovering statistics using IBM SPSS statistics. 4 edn. London: SAGE Publications, 2013.

32 SOU. The elderly care in the pandemic 2020. corona Commission, 2020. Available: https://coronakommissionen.com/ [Accessed 30 Jan 2021].

33 Estabrooks CA, Straus S, Flood CM. Restoring trust: COVID-19 and the future of long-term care. Royal Society of Canada, 2020. Available: https://rsc-src.ca/en/themes/long-term-care [Accessed 21 May 2021].

34 Liljas AEM, Brattström F, Burström B, et al. Impact of Integrated Care on Patient-Related Outcomes Among Older People - A Systematic Review. Int J Integr Care 2019;19:1-6.

35 Doheny M, Agerholm J, Orsini N, et al. Impact of integrated care on trends in the rate of emergency department visits among older persons in Stockholm County: an interrupted time series analysis. BMJ Open 2020;10:e0361182.

36 Stockholm Gerontology Research Center. Äldres resa till, genom och ut från sjukhuset i Stockholms län: En lägesbeskrivning inför lagen om samverkan vid utskrivning från sluten hälso-och sjukvård [Older people's way through hospital care in Region Stockholm: A description of the situation before the implementation of the Act on coordinated discharge from hospital care] 2018. Vol 1. Reports Stockholm Gerontology Research Center, 2018. 